\section{THE METROPOLITAN UNIVERSITY.}

\section{To the Editor of The LanceT.}

$S_{I R},-A s$ the enclosed letter to the $R$ t. Hon. T. S. Rice relates to a matter of great importance at the present time, I shall be obliged by its insertion in your pages. I am, Sir, yours, \&c., Joun Epps, M.D.

89, Great Russell-street, Dec. 17, 1835.

To the Right Honourable Tromas Spring Rice, M.P., Chancellor of the Exchequer.

Sir,-When Vice clothes itself in the garb of Virtue, she is the more dangerous, because more difficult of detection; and hence, sometimes, even the good embrace her, without being aware, until the consequences of the embrace become apparent, of the hideous being they have acknowledged.

Thus attired is MonopoLY.

To the hatefulness and the injuriousness of monopoly, the Government of which you were and are now a member, have testified by the measures introduced in various sessions, to destroy, or at least to mitigate, the evils of some of the most extensive monopolies. So that every unbiassed man, looking upon these proceedings of the Government, has come to the conclusion that the necessity is seen, on the part of the Ministry, of abolishing all monopolies, so far as such abolition can be effected with safety.

One monopoly that stands most in need of abolition is exhibited by the Universities of Oxford and Cambridge. These Universities exclude all save those who are of a particular creed, and thus make the honours of literature and science to depend, not upon a man's talent, but upon his religious opinions.

The atrocity of the monopoly thus created is now very generally felt, and a general cry for the abolition of the unsalutary power perpetuating this monopoly, has been raised through the kingdom.

To that cry it has not been possible, on account of the peculiar constitution of the Universities of Oxford and Cambridge, to pay any effectual regard.

What has happened? The evil is felt. Individuals, not content to wait till the removal of the evil shall be effected by the influence of public opinion, acting through the House of Commons, and through that House on the House of Lords, determined to realize the privilege of obtaining the power of conferring honorary degrees without the degrading condition of submitting to a particular creed.

These individuals, instead of going to the Legislature, and demanding that an University should be established in the Metropolis, combined together; and, by subscribing for certain shares, constituted a large proprietary of shareholders, who determined to raise an edifice, which, with its adjuncts of teachers, should be called "The University of London."

The building was raised; the teachers were appointed, and the system of instruction was commenced. Forthwith an attempt was malle by them to obtain a CHARTER, not merely of incorporation, but to secure to them the power of conferring degrees.

It seemis, moreover, from the nature of the motion of Mr. Tooke, in the House of Com. mons, on March 26th, 1835, that a royal charter of incorporation had been drawn up and approved of by the law officers of the Crown in the year 1831.

Now, Sir, what would have been the consequence of giving such a charter* to the London University? What but the establishing another monopoly? a monopoly of teachers.

The proof is easy. The ohject of a college and of all schools is to teach. The skill of the teachers, and the means possessed for the manifestation of that skill, ought to be the only grounds upon which any pre-emi. nence can be claimed. Each teacher becomes interested in communicating scientific truths in the most clear and comprehensive manner. There is a beneficial, a scientific rivalry, pregnant with advantage. But if there be any exclusive advantages possessed by particular teachers, what is the consequence? To render this apparent, take two lecturers, $A$ and $B$, both of whom are equally talented. They make known that they lecture. They are equal in talent to instruct, and in the possession of means for instruction. Those anxious to be instructed hear of their intentions, and determine to place themselves under their instructions, some under $A$ and some under $B$. But, by scme contrivance, $B$ has managed to obtain a peculiar and exclusive advantage; namely, that his pupils will be enabled, by attending his lectures, or teach. ings, to obtain a degree, which the pupils of $A$ will not. Does it not follow that plus advantage added to equal talent must give $B$ an injurious superiority? And, in addition, does it not follow that this superiority must be injurious to $A$ ? And is not the possession of such a superiority a manifestation of the exclusive principle, $-a$ monopoly of the worst character?

Such a monopoly would have been established, had the London University obtaired the charter which they sought. But they would have obtained a monopoly of a more glaring character, had the charter sought for been granted.

The senate would have been the examining body. The professors, or the teachers, would have become the examiners of their own pupils.

* This charter included the power of giving medical regrees. 
It is true, Sir, that the plan now proposed by the Government obviates the latter evil. And in this view of this important matter every enlightened mind must agree with Mr. Hume, that " the Government is in the novel position of taking the lead of them" (the proprietors of the University) in the general liberality of the plan."

What then is proposed by the Government? It may be stated thus :-

1. That a board of examiners, to be termed the University of London, shall be authorized by charter to confer degrees.

2. That pupils from University and King's Colleges shall be admitted to examination.

3. And that any other bodies for education, whether incorporated or unincorporated, may, from time to time, be named by the Crown, and their pupils be admitted to examination for degrees.

Such are the intentions of Government; intentions indicative evidently of the fact, that degrees are to be conferred upon the prosecutors of every department of learning and of knowledge, divinity excepted.

To this no liberally-minded individual can object. But, in developing the intention, one circumstance occurs which mars the beauty of the plan. It is this, that while "the University" can confer all degrees save those in divinity (an excellent exception), the individuals on whom these degrees are to be conferred are not all who may be qualified by their learning and knowledge, - not all who have laboured hard to acquire every necessary information, but those only who have been educated at "any chartered college within the Metropolis."

Now, Sir, is not this giving a positive monopoly to the teachers in chartered colleges? Is not this as much as asserting that the education of students is better within the walls of a chartered college than within the walls of any other build ing? Is not this a spirit of intellectual consecration of bricks and mortar? Is not this a sacrifice to the god of wealth, because the largeness of the iuilding seems to have some weight in the matter? Finally, Sir, is it not saying to those beginning their studies in London, "Geritlemen, go to the King's College and to the London University (to be called "London University College"); become pupils there, for there you will have talented lecturers: and there, in addition, you will be able to gain honorary degrees?"

But, Sir, it may be said, that the Government plan is not so exclusive as this; for it is expressly stated, in the communication from Downing-street to the Council of the Lordon University, dated Aug. 19, 1835, that "Any other bodies for education, whether incorporated or unincorporated, may, from time to time, be named by the Crovn, and their pupils to be admitted to examination for degrees."

But, Sir, it is stated, in the preceding clause, that a particular class of pupils is at once admissible to examination for degrees; and this particular class consists of pupils from University and King's Colleges.

Here, Sir, is given at once a priority to those educational bodies over other schools,and why? Are they better teachers at these thus styled "Colleges" than at other schools? Personal comparisons would be invidious, and therefore should be avoided. But it may be asked without fear, Is the education at either of these institutions superior, in refer ence to the production of real medical qualification for medical practice, to that given at the "private" schools, as they are called?

Let, Sir, an application be made to the examining Boards of the Apothecaries' Company and of the College of Surgeons, and let a report be presented from each body, of the pupils passed or rejected, as belonging to individual schools; and I myself, as an individual private lecturer, am quite willing to abide by the result, as a testification of the nature and of the sufficiency of medical education, as given at the private schools.

Is it then just, Sir, that the pupils of any one institution, or of any institutions, should have the priority given them of starting in this intellectual race for intellectual honours, in advance of the pupils belonging to other institutions?

I sincerely believe, from various sources, that it is the wish of Government to act in this matter with the greatest fairness; but is it not apparent that the naming the pupils of the London University College and of King's College is giving an undue priority?

It may be asked, "What then do you propose?"-I propose, Sir, that the Government of this country, recognising the grand truths, that science has no country, that scientific men have generally been those who have received no aids of collegiate education, should declare, that

Literary and scientific honours shall be open to every individual, who can prove himself qualified to possess tilose honours:

And that, in addition,

Those honours being gained, the individuals gaining them shall have every legal privilege connected with the qualification.

With regard to the latter point, it wonld evidently be absurd to give an honorary degree as indicative of qualification, and then, afterwards, to require the qualified to pass another ordeal, previous to the realiza. tion of the benefits of such qualification.

It is true that such a plan would require the sweeping away, in the present state of society, of many scientific, or rather pseudoscientific, nuisances; but the gain would be immense; the loss would be nothing.

And what a noble menento of the Government such a proceeding would be! What a pleasurable satisfaction would arise 
in the mind of yourelf, a member of such a Government, in contemplating the fruits of such a labour! And finally, what a thought to console at the close of an honourable life,_" I have been an instrument in removing a mighty barrier to the diffusion of education and enlightenment amongst the people."

Trusting, Sir, that you are capable of appreciating the high behests connected with the decision of Government on this important question, I have the honour to remain, your obedient servant,

John EPps,

Lecturer on Materia Medica and Chemistry, and Director of the Ruyal Jennerian and London Vaccine Institutions.

\section{METROPOLITAN UNIVERSITY DEGREES.}

\section{REPLY TO THE TETTER OF "A KING'S COLLEGE STUDFNT."}

To the Editor of The Lancet.

Sra, - I did not expect that the suggestions which 1 offered in THE LANCET of Dec. 5, respecting the conditions of granting degrees in the New Metropolitan University, would have met with the opposition which "A King's College Student" has offered them. I did not expect to be so hastily dignified with the title of "opponent," by a gentleman who is already in possession of those advantages which $I$ merely suggested should be exterded to others. But, Sir, as he has appealed to the public to decide which of us is right, $I$ arn induced to reply to his remarks, and sball then leave the subject with perfect confidence in your hands, satisfied also in what manner the public will ultimately decide on the question. $\mathrm{My}$ opponent takes occasion to reprove me for calumniating a body of mon who are "not yct called into political existence." How can I have effected that impossibility? However, the commencement of my letter shows that I did not refer to any set of men, but to a proposed system, which I conceived to be objectionable. But I proceed to his objections.

Certificates of moral character, he says, are frequently forged. To this I reply, that a written clearacter ought not to be accepted, unless some means are taken to ascertain that it is authentic.

$\mathrm{He}$ objects to allowing young men to graduate without having been College Stu. dents, because, though it might benefit a few, it would ruin the majority, fior many who do now attend lectures occasionally, wonld not then, he says, attend lectures at all. And suppose students did not attend lectures at all? Suppose they did not study? Why then they would be certain of not obtaining a degree. In fact; it is more than probable; that instead of the new system causing ruin to any one, it would arouse students to a sense of the necessity of profound study, and induce them to seize every opportunity of adding to their mental and professional attainments.

My opponent imagines that I think that students who neglect the lecture-room, are more profitably employed elsewhere in study. Those gentlemen who neglect the lecture-room do so, I should suppose, for far less noble pursuits than those of science. I quite admit the benefits of oral instruction. I merely argue that if a student does, without its aid, obtain as much knowledge as one who is in possession of its advantages, lie ought to be entitled by law to the same honours, and the same standing in society.

My opponent next says, that a man can* not obtain sufficient knowledge from books alone, to qualify him to possess a diploma. I reply, that a Board of Examiners can fully test this. They can test his knowlerlge of anatomy and the operations of surgery on the dead body, his knowledge of the praetice of medicine in the wards of an lrospital, his knowledge of chemistry (if need be) in the laboratory.

Ire says, that the duration of the examination which would be necessary under the new system, would be so long as to render it impracticable in operation. I reply that a lengthy examination is not impracticable. As it is designed to secure the public against incompetency, the examiners would undoubtedly be fnlly remunerated for their time, and there is no other point than that in question. My opponent himself says, that certificates are often forged (and I know that they are often giren without being deserred); how then can he support a system in which he would allow certificates to play any part in the conditions of granting diplomas?

His last, his most startling, and his only sincere ground of objection, is hased on the supposition that the new system would tend to deprire the graduates, as a body, of their respectability. Why, truly, if respectability consists in the exclusion of all but the rich from literary or scientific honours, the new system most certainly would ensure respectability to the class of graduates; but if, as I apprehend, respectability helongs to the mind and not to the pocket, then what is the worth of my opponent's objection? For' although he may exult at this exclusive system, alchough he may feel indignant at the thought of a "farmer's or a tradesman's son" aspiring to the honours of learning and skill, yet I can tell him that farmers' and tradesmeu's sons deem it as much their right to aspire to reach the eminences of science, and will demand (if they should not have learnt from the corruption of a bad system to despise them) equal "honours" with those, who though rich, possess no greater 